\title{
Epstein-Barr Virus-Transformed B-Cell Line (DV-1) Derived from Bone Marrow of a Patient with Severe Combined Immunodeficiency and Immunoblastic Lymphoma
}

\author{
HOWARD M. ROSENBLATT, DOROTHY E. LEWIS, JEFFREY SKLAR, MICHAEL L. CLEARY, \\ NIRMI PARIKH, NAOMI GALILI, JEROME RITZ, AND WILLIAM T. SHEARER \\ Departments of Pediatrics, Microbiology, and Immunology, Baylor College of Medicine, Houston, Texas \\ [H.M.R., W.T.S., D.E.L.]; The David Center, Texas Children's Hospital [H.M.R., W.T.S., N.P.]; the Howard \\ Hughes Medical Institute, Houston, Texas [D.E.L.]; the Division of Tumor Immunology, the Dana-Farber \\ Cancer Institute, Boston, Massachusetts [J.R.]; and Department of Pathology, Stanford University School of \\ Medicine, Stanford, California [J.S., M.L.C.]
}

\begin{abstract}
An Epstein-Barr virus-transformed B-cell line derived from a patient with severe combined immunodeficiency who died of a lymphoreticular malignancy has been characterized. The line derived from bone marrow cultures and designated DV-1 shows surface and cytoplasmic IgM and staining with fluorescent monoclonal antibodies against immunoglobulin heavy and light chains $\mu, \delta$, and $\kappa$, Dr, and several other B-cell surface antigens. DV-1 secretes $\operatorname{IgM}_{\kappa}$ and demonstrates monoclonality on analysis of immunoglobulin heavy and light chain gene rearrangement patterns. Incubation with either phytohemagglutinin or pokeweed mitogen failed to cause significant stimulation of proliferation of DV-1 and another EBVtransformed B-cell line derived from an immunologically normal host (LA-350), whereas incubation with Staphylococcus aureus Cowan strain 1 led to significant inhibition of DV-1 and LA-350. Rabbit IgG antibody specific for human immunoglobulin $\mu$-chains produced a dose dependent stimulation of both lines. The responses of DV-1 and LA-350 to mitogens and anti- $\mu$ were not as high as those of normal peripheral blood lymphocytes. This spontaneously derived Epstein-Barr virus-transformed B-cell line from a patient with severe combined immunodeficiency demonstrated functional characteristics similar to a B-cell line derived from an immune competent host. While these cells spontaneously incorporate $\mathbf{2 0 0}$ times more thymidine than normal resting peripheral blood lymphocytes, they retain their ability to be modulated by antiimmunoglobulin, and staphylococcal Cowan strain 1, but are unresponsive to the effects of B-cell growth factor. (Pediatr Res 21: 331-337, 1987)
\end{abstract}

\section{Abbreviations}

anti- $\mu$, antiserum to $\operatorname{IgM}(\mu$ specific)

BCGF, B-cell growth factor

EBV, Epstein-Barr virus

Received October 30, 1985; accepted November 13, 1986

Address reprint requests and correspondence to Howard M. Rosenblatt, M.D., Section of Allergy and Immunology, Department of Pediatrics, Baylor College of Medicine, One Baylor Plaza, Houston, TX 77030.

This work was supported in part by Baylor Research Grant 83-84P-37 (Public Health Service Grant RR-05425); a special grant from Texas Children's Hospital the David fund of Texas Children's Hospital; grant PO1-AI21289 from the National Institutes of Health; and a General Clinical Research grant RR-00188. J.R. is a scholar of the Leukemia Society of America.
ELISA, enzyme-linked immunosorbent assay FCS, fetal calf serum

HEPES, 4-(2-hydroxyethyl)-1-piperazineethanesulfonic acid

LBL, lymphoblastoid line

NK, natural killer cell

PBL, peripheral blood lymphocytes

PHA, phytohemagglutinin

PWM, pokeweed mitogen

$\mathrm{R} / \mathrm{H}$ anti- $\mu$, rabbit antihuman IgM ( $\mu$-chain specific)

$\mathrm{SAC}$, Staphylococcus aureus Cowan strain 1 formalin fixed organisms

SCID, severe combined immunodeficiency

$\left[{ }^{3} \mathrm{H}\right] \mathrm{dThd}$, tritiated thymidine

$\mathbf{F a b}_{2}{ }_{2}$ anti- $\mu$, antihuman IgM ( $\mu$-chain specific)

CALLA, common acute lymphocytic leukemia antigen

The polyclonal activation of immunoglobulin production and the proliferative transformation of a subpopulation of B-cells after infection with EBV has been known for some time (1). The morphological, proliferative, and functional characteristics of Bcell lines derived both spontaneously from EBV-infected hosts and by in vitro transformation of B-cells by certain strains of EBV have been reviewed by Nilsson and Klein (2). EBV transformation with malignant polyclonal and monoclonal proliferation of B-cells has been documented in a number of reports in both primary and secondary immune deficient hosts and has recently been reviewed (3).

We report initial studies characterizing a LBL derived from a 12-yr-old patient who died of an EBV-associated lymphoproliferative malignancy after bone marrow transplantation for SCID. The phenotypic and functional characteristics of this line are described and compared to another LBL derived from an immune competent patient (LA-350) and to normal peripheral blood lymphocytes.

\section{MATERIALS AND METHODS}

Cell lines. Cells were obtained from vertebral bone marrow at postmortem examination (approximately $1 \mathrm{~h}$ after death) and incubated for $24 \mathrm{~h}$ in modified Eagle's minimum essential media supplemented with penicillin and streptomycin, $10 \%$ heat inactivated FCS, and HEPES buffer. Subsequently, the cells were 
cultured at $37^{\circ} \mathrm{C}$ in medium containing RPMI 1640 and $15 \%$ heat inactivated FCS with a bicarbonate-5\% $\mathrm{CO}_{2}$ buffer system. Unused aliquots of cells were frozen viably and stored in liquid nitrogen. Cell line LA-350 derived by EBV transformation of peripheral blood B lymphocytes from a patient with neuroblastoma prior to any therapy was the kind gift of Dr. R. C. Seeger (UCLA Center for Health Sciences, Los Angeles, CA) and was maintained in Waymouth's media supplemented with $15 \%$ FCS and antibiotics. PBL were obtained from normal adults and purified in a mononuclear cell suspension using a Ficoll-Hypaque gradient (4).

Cell surface antigen phenotyping. Nonsynchronous cell cultures were examined for a number of cell surface antigens defined by monoclonal antibodies obtained from commercial sources. Standard methods of indirect immunofluorescence followed by flow cytometry using a Coulter EPICS V and computerized analysis of the histograms by the IMMUNO program (Coulter Electronics, Hialeah, FL) was used to determine percentages of cells positive for each marker. A panel of monoclonal antibodies defining well accepted surface antigens commonly associated with certain functional and maturational features of $\mathrm{T}$ and $\mathrm{B}$ lymphocytes and NK was selected to characterize the DV-1 line. We routinely utilize most of these markers in characterizing the lymphocytes of our immunodeficient patients including the patient from whom DV-1 was derived (5). In addition the patterns of expression of these markers has been used to describe the phenotypic characteristics of a number of lymphoreticular tumors and cell lines. Monoclonal antibodies against the T-cell markers T3, T4, T8, T9, T10; the B-cell markers B1, B4, B7, DR (Ia), and immunoglobulin heavy $(\mu, \gamma, \delta)$ and light $(\kappa, \lambda)$ chains were obtained from Ortho Pharmaceuticals, Raritan, NJ. Monoclonal antibodies to B-cell markers B2 and Leu 12 and NK markers Leu 11, Leu 7, and NKH-1; and myeloid markers J5 and M5 were purchased from Becton Dickinson Monoclonal Inc., Mountainview, CA. Monoclonal antibody 37.1 was produced against $\mathrm{B}$-cells isolated from a patient with hypogammaglobulinemia and represents a middle maturation B-cell surface antigen expressed on CLL cells but not on ALL cells (6). Tissue typing was performed using standard microcytotoxicity methods by Dr. M. S. Pollack at Baylor College of Medicine Tissue Typing Laboratory.

Cytogenetics. Chromosome analysis was performed using Gbanding techniques by Dr. D. Ledbetter at Kleberg Cytogenetics Laboratory, Baylor College of Medicine Houston, TX. Analysis was performed on several occasions using both mitogen stimulated and nonstimulated cells.

$E B V$ detection. Infection of cells with EBV was detected by two methods. An anti-complement immunofluorescence assay was used by Dr. C. Sumaya, University of Texas, San Antonio, TX to detect the presence of $\operatorname{EBNA}(5,7,8)$. The quantitation of EBV genome in DNA isolated from DV-1 was performed using the standard slot blot technique and hybridization with a ${ }^{32}$ P-labeled EcoRI-B fragment of EBV DNA provided by Dr. G. Miller (Yale University, New Haven, CT) $(5,9)$. This probe recognizes a noniterated sequence of the EBV genome.

Analysis of immunoglobulin gene rearrangements. DNA isolated from DV-I was analyzed for heavy and light chain gene rearrangement using $J_{H}$ heavy and $k$ light chain probes according to previously described methods $(5,10)$.

Immunoglobulin determination. Immunoglobulin synthesis was determined by ELISA assay of the culture supernatants according to published methods $(11,12)$. Briefly, either goat antihuman $\operatorname{IgM}, \mu$-chain specific or goat antihuman $\mathrm{IgG}$, heavy and light chain specific (Cappel Laboratories, Malvern, PA) was coupled to polystyrene beads using a $0.1 \mathrm{M}$ carbonate buffer $\mathrm{pH}$ 9.4 overnight at $4^{\circ} \mathrm{C}$. The excess binding sites were saturated by incubation of the beads for $2 \mathrm{~h}$ at room temperature with a $1 \%$ solution of bovine serum albumin (Sigma, St. Louis, MO) in the same carbonate buffer. The antibody-bound beads were washed alternately with PBS pH 7.4 and $0.05 \%$ Tween-20 in PBS and finally stored in a $1 \%$ solution of heat inactivated FCS in PBS with $0.05 \%$ sodium azide at $4^{\circ} \mathrm{C}$ until used. Solutions to be assayed were incubated in $50 \mu$ l volumes diluted with $200 \mu \mathrm{l}$ of $1 \% \mathrm{BSA}$ in PBS for $1 \mathrm{~h}$ at room temperature. Beads were washed with $0.05 \%$ Tween-20 in PBS and incubated for $1 \mathrm{~h}$ with alkaline phosphatase conjugated goat antihuman IgM ( $\mu$-chain specific) or antihuman IgG (heavy and light chain specific) antiserum (Cooper Scientific, Cochranville, PA). Beads were washed again and finally incubated for $30 \mathrm{~min}$ with $250 \mu \mathrm{l}$ of $5 \mathrm{mM} \mathrm{p}$ nitrophenylphosphate substrate (Sigma) in $1.0 \mathrm{M}$ diethanolamine buffer at $\mathrm{pH} 9.8$ (13). The reaction was stopped with 250 $\mu \mathrm{l}$ of $1.0 \mathrm{M} \mathrm{NaOH}$ and the samples brought to a final volume of $2.0 \mathrm{ml}$ with PBS. Absorption at $405 \mathrm{~nm}$ was read using a Gilford spectrophotometer and the immunoglobulin content of the supernatants was determined from the standard curve generated using dilutions of normal human serm pools of known IgG, IgM, and $\operatorname{IgA}$ content.

Cell culture stimulation assays. Stimulation with the mitogens PHA (Burroughs Wellcome, Research Triangle Park, NC) and PWM (GIBCO, Grand Island, NY) was performed in 96-well microtiter plates according to published methods (14). Normal PBL control cultures consisted of $1 \times 10^{5}$ cells/well while cultures with LBL (LA-350, DV-1) contained $1 \times 10^{4}$ cells/well. Cells were cultured with 3 concentrations of PHA $10,1,0.1 \mu \mathrm{g} / \mathrm{ml}$ ) and 3 dilutions of PWM (1:640, 1:2500, 1:5120) for $96 \mathrm{~h}$ at $37^{\circ}$ $\mathrm{C}$ in $5 \% \mathrm{CO}_{2}$. The cultures were pulsed with $\left.{ }^{3} \mathrm{H}\right] \mathrm{dTh}$ (Amersham, Arlington, IL) at a final concentration of $10 \mathrm{mCi} / \mathrm{ml}$ for the last 20-24 h of incubation, harvested onto fiber filters using a multisample vacuum harvester, solubilized and suspended in scintillation fluid, and counted by liquid scintillation spectrometry. Control cultures were treated identically only with the mitogen omitted. In timed studies of PWM stimulation, cultures always were pulsed for the final $20-24 \mathrm{~h}$ but harvest times varied from 24 to $96 \mathrm{~h}$.

Cells also were incubated with rabbit antibodies directed against IgM ( $\mu$-chain specific) with and without supernates from 72-h PHA-stimulated normal pooled PBL cultures. Sredni et al. (15) demonstrated the presence of BCGF activity in such supernates. Cultures were set up with $5 \times 10^{4}$ LBLs or $1 \times 10^{5}$ normal PBL. Cells were incubated for $48 \mathrm{~h}$ at $37^{\circ} \mathrm{C}$ with varying dilutions of either intact $\mathrm{R} / \mathrm{H}$ anti- $\mu$ or rabbit $\left(\mathrm{Fab}^{\prime}\right)_{2}$ anti- $\mu$ (Cappel Laboratories, Cochranville, PA). During the final 18-24 h, 2 $\mathrm{mCi}$ of $\left[{ }^{3} \mathrm{H}\right] \mathrm{dTh}$ was added to each $200-\mu$ l culture. Cells were harvested and counted by liquid scintillation spectrometry as above. Those cultures performed in the presence of BCGF contained a final concentration of $20 \%$ BCGF-containing supernate and were handled in the same manner. Cultures stimulated with SAC contained $1 \times 10^{5}$ normal PBL or $1 \times 10^{4}$ LBL (DV- 1 or LA-350) and varying dilutions of SAC (Bethesda Research Laboratories Inc., Gaithersburg, MD.) either with or without $20 \%$ BCGF containing supernates. Cultures were pulsed as above during the last $24 \mathrm{~h}$ of incubation at $37^{\circ} \mathrm{C}$ in $5 \% \mathrm{CO}_{2}$ atmosphere and cells were harvested and counted in a liquid scintillation counter as above.

\section{RESULTS}

Establishment of cell line $D V-1$. Within the first 3-5 days of culture all bone marrow cultures contained a population of adherent fibroblast-like cells and a polymorphic population of nonadherent cells in suspension. Successful subculturing of nonadherent cells was initially dependent on the presence of this autologous adherent feeder layer. Commerical fibroblast (WI-38) monolayers were not capable of supporting growth of the nonadherent cells in suspension. After $6-8 \mathrm{wk}$ of subculturing bone marrow cells with adherent feeder layers, the lymphoblastoid cells became capable of growth independent of the adherent cell layer. It is these bone marrow derived, feeder layer-independent cells which were termed DV-1 and were subsequently characterized. 
Growth characteristics. DV-1 cells were pleomorphic and grew in suspension in large aggregates of cells easily disrupted by gentle pipetting. An adequate cell density was obtained by subculturing every 3-4 days at 1:4 to $1: 10$ dilution in fresh media. Nonsynchronous cell cultures had an approximate doubling time of 18 $24 \mathrm{~h}$ and demonstrated a normal 46XY karyotype. Cells show small pseudopod-like projections on their surface when growing in suspension (Fig. 1) which is a commonly seen feature of transformed B-cells $(2,15)$. The LA-350 cells grow in similar aggregates, have a doubling time of approximately $12-18 \mathrm{~h}$, and demonstrate the same pleomorphism and membrane projections as described above.

EBV studies. Virtually $100 \%$ of the cells demonstrated EBV infection by immunofluorescence for EBNA. Quantitation of
EBV DNA showed approximately 5-10 genome equivalents per DV-1 cell (Fig. 2).

Cell surface markers. Immunofluorescent staining with polyvalent antihuman Ig reagents showed positive fluorescence with typical capping and aggregation of surface immunoglobulins seen with peripheral blood B-cells. Frequency histograms of the cells stained for several common surface markers using indirect immunofluorescence and flow cytometry are illustrated in Figure 3. The cell line DV-1 appears to be a B-cell-derived line as there is no significant detection of typical T cell markers using monoclonal reagents and 97 and $91 \%$ of the cells were positive for Dr and B1 markers, respectively. Furthermore, the majority of cells bear IgM heavy chains and $\kappa$ light chains on their surface while fewer than $20 \%$ show detectable $\operatorname{IgG}$ or $\lambda$ light chains. In addi-

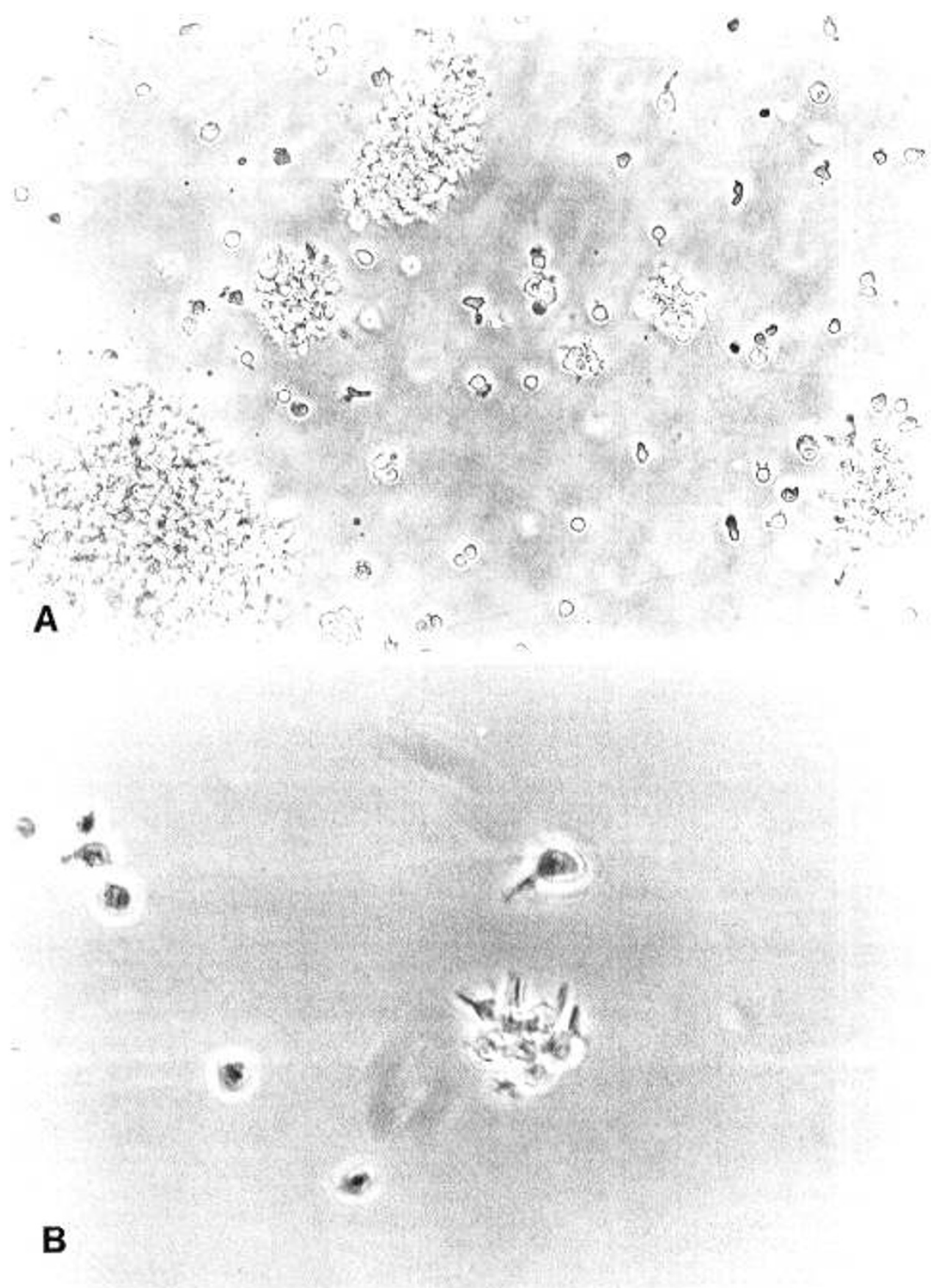

Fig. 1. Phase contrast photomicrographs of DV-1 cells demonstrating typical growth patterns in large and small cell aggregates $(A)$ and pseudopodlike cytoplasmic projections $(B)$. Photographs taken through a Nikon inverted phase contrast microscope with a Nikon HFM automatic metcring system at $100 \times$ and $200 \times$, respectively, using Kodak Plus X Pan ASA 125. 


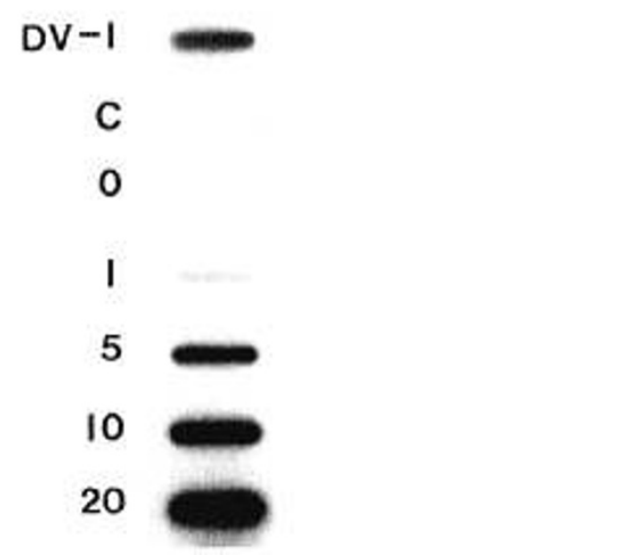

Fig. 2. Slot blot analyses of EBV DNA from the DV-1 cell line and control specimens. Five $\mu \mathrm{g}$ of DV-1 DNA and human sperm DNA $(C)$ were applied to the membrane. Different amounts of EBV DNA corresponding to varying numbers of genome equivalents, as indicated by numbers in the figure, were also applied to the membrane for quantitation of the results.

tion, $85 \%$ of unsynchronized cells express $\operatorname{IgD}$ on their surfaces. Analysis for the presence of a number of other monoclonal antibody-defined surface antigens demonstrated the absence of myeloid markers, J-5 or CALLA, the monocyte marker M-1, and the NK markers detected with two monoclonal reagents (leu 7 and leu 11). The intensity shift of the entire population with $\mathrm{NKH}-1$ staining probably represents nonspecific Fc binding and not true expression of the NKH-1 antigen.

Percentages of these markers on the LBL lines DV-1 and LA350 are summarized in Table 1 . It is interesting that the premortem PBL of the patient displayed marked reactivity with $\mathrm{B} 1, \mathrm{Dr}$, T10 and NKH-1 antibodies (5).

Gene rearrangement studies. Autoradiograms for both immunoglobulin heavy chain and $\kappa$ light chain gene rearrangements (Fig. 4) each showed one germline band and one clonally rear-' ranged nongermline band. The findings of a single intense rearranged band for both heavy and light chain genes and the equal intensity of the germline and rearranged bands suggest the presence of a monoclonal population of DV-1 cells in which one allele is rearranged and the other is not. Interestingly, the patterns noted in the autoradiogram from DV-1 did not match the patterns of any of the tumors found at postmortem examination of the patient from whom the line was derived. Two monoclonal lesions found in the lung and jejunum showed only $\kappa$ light chain gene rearrangement. Lesions from several other locations showed oligoclonal $\mathbf{J}_{11}$ banding patterns and evidence for rearrangement of $\kappa$ and $\lambda$ genes (5).

Proliferative studies. The dose-dependent proliferative response of DV-1, LA-350, and control PBL to PHA and PWM is illustrated in Table 2. Compared to the usual proliferative responses of normal PBLs to these mitogens, only a minimal response was seen in either DV-1 and LA-350, respectively, at the highest concentration of PHA. These trends began as early as $48 \mathrm{~h}$ incubation and were still detectable after incubation for $96 \mathrm{~h}$ with the appropriate mitogens. To determine if there was a time-dependent effect of PWM on these cells, incubations were carried out using the highest PWM concentration (1:640 dilution) for various lengths of time from 24 to $96 \mathrm{~h}$. The results (data not shown) indicate minimal PWM responsiveness of both LBLs at all time points.

Effect of $R / H$ ant $i-\mu$. Preliminary titration studies using various concentrations of anti- $\mu$ showed optimal stimulation of both PBL and LBLs at $48 \mathrm{~h}$ (data not shown). Incubation of PBL and LBL for $48 \mathrm{~h}$ with anti- $\mu$ at several concentrations from $0-175$
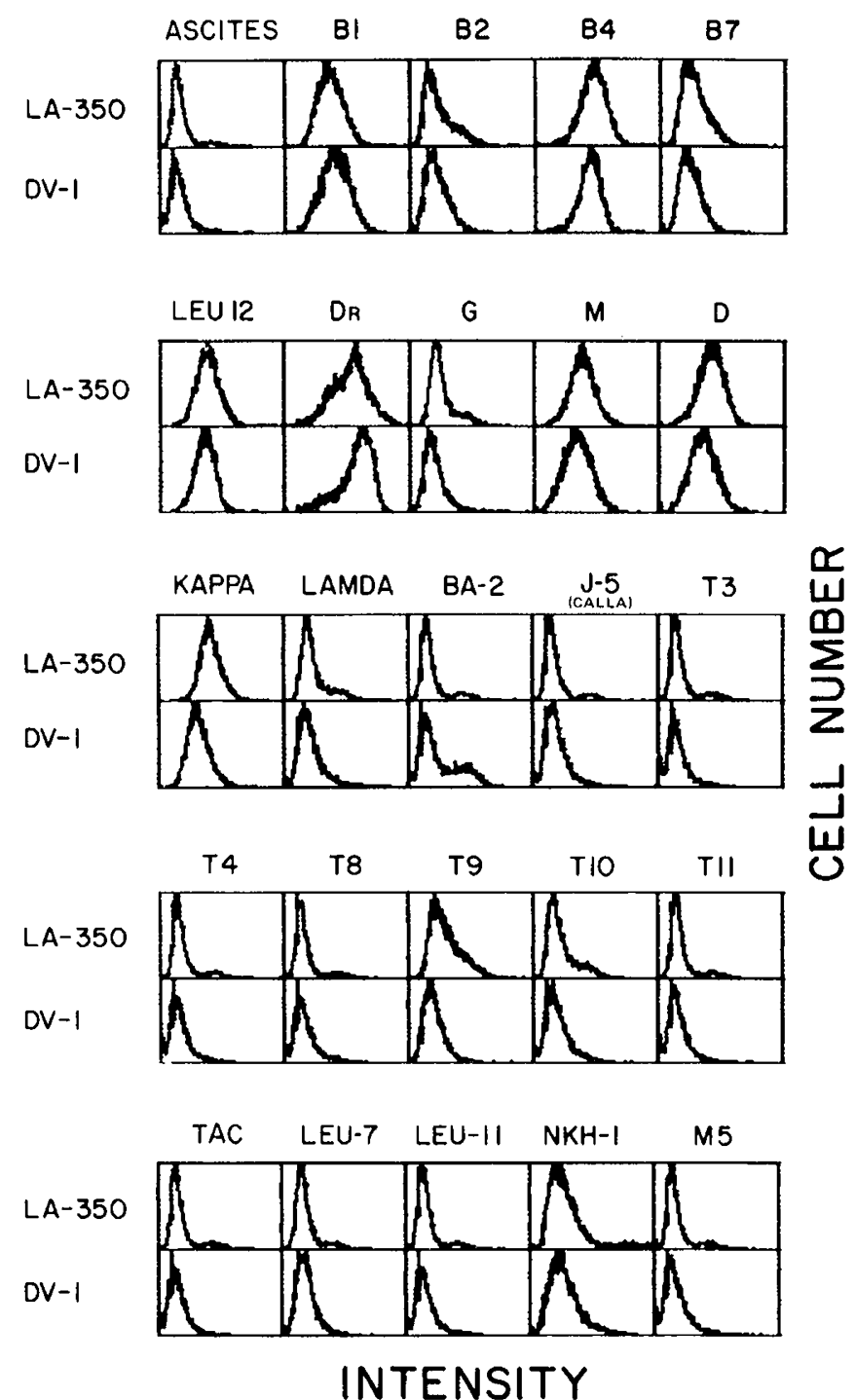

Fig. 3. Immunofluorescence histograms for cell surface markers on LA-350 and DV-1 cells using FITC conjugated monoclonal antibodies as described in "Materials and methods." A total of 20,000 cells was counted for each surface marker

$\mu \mathrm{g} / \mathrm{ml}$ produced a dose-dependent stimulation of thymidine incorporation of all three cell types (Table 3 ). This effect appeared to be specific since previous studies utilizing irrelevant proteins such as control rabbit antiserum, murine monoclonal antibodies against human Thy- 1 , and a human neuroblastoma associated surface antigen caused no alteration in cell proliferation (data not shown). From the data shown in Table 3 it appears that while the BCGF containing supernatant enhanced the proliferative effects of anti- $\mu$ on PBL by 40 to $240 \%$ at different concentrations of anti- $\mu$; no such enhancement was seen for DV-1 or LA-350. There was not a significant difference between stimulation with the intact Ig molecule as compared with the divalent $\mathrm{F}\left(\mathrm{ab}^{\prime}\right)_{2}$ fragment (data not shown). Interestingly, at the lower concentrations, stimulation was more consistent for the LBLs than for normal PBLs.

Proliferative effects of $S A C$. Preliminary studies established that maximal $\left[{ }^{3} \mathrm{H}\right] \mathrm{dTh}$ incorporation by normal unseparated PBLs occurred at $96 \mathrm{~h}$ and by LBL at $72 \mathrm{~h}$ over a wide range of dilutions of SAC. The proliferative effects of SAC on PBL, DV1 , and LA-350 over a wide range of dilutions at $72 \mathrm{~h}$ are shown in Table 4. The typical stimulatory effect of SAC is demonstrated for PBL with a 6-fold increase in $\left[{ }^{3} \mathrm{H}\right] \mathrm{dT}$ Thd uptake at a 1:5000 
Table 1. Phenotypic Characteristics of DV-1 and LA-350*

\begin{tabular}{|c|c|c|c|c|c|c|c|c|}
\hline $\begin{array}{c}\text { B-cell } \\
\text { markers: }\end{array}$ & DV -1 & LA-350 & $\begin{array}{c}\text { T-cell } \\
\text { markers: }\end{array}$ & DV -1 & LA-350 & Other: & DV-1 & LA-350 \\
\hline B1 & 91 & 93 & T3 & 2 & 6 & $J-5$ & 11 & 5 \\
\hline B2 & 27 & 32 & $\mathrm{~T} 4$ & 2 & 5 & M5 & 8 & 5 \\
\hline B7 & 39 & 55 & $\mathrm{~T} 8$ & 4 & 4 & $\mathrm{BA}-2$ & 33 & 9 \\
\hline \multirow[t]{2}{*}{ B4 (Leu 12) } & 96 & 97 & & & & 37.1 & 72 & 70 \\
\hline & & & & & & $\mathrm{TAC}$ & 2 & 7 \\
\hline Ia (Dr) & 97 & 97 & NK markers: & & & $\mathrm{T} 9$ & 16 & 61 \\
\hline $\operatorname{IgG}$ & 15 & 16 & $\overline{\text { Leu } 7}$ & 12 & 7 & & & \\
\hline IgM & 83 & 93 & Leu 11 & 4 & 4 & & & \\
\hline $\operatorname{IgD}$ & 85 & 95 & & & & & & \\
\hline k & 84 & 98 & & & & & & \\
\hline$\lambda$ & 20 & 16 & & & & & & \\
\hline
\end{tabular}

* $10^{4}$ cells stained with each monoclonal antibody compared with control second step stained cells. Values represent the percent of the total mononuclear cell fraction positive for each respective marker. Population shifts of greater than $20 \%$ were required before considering a cell positive for any marker.

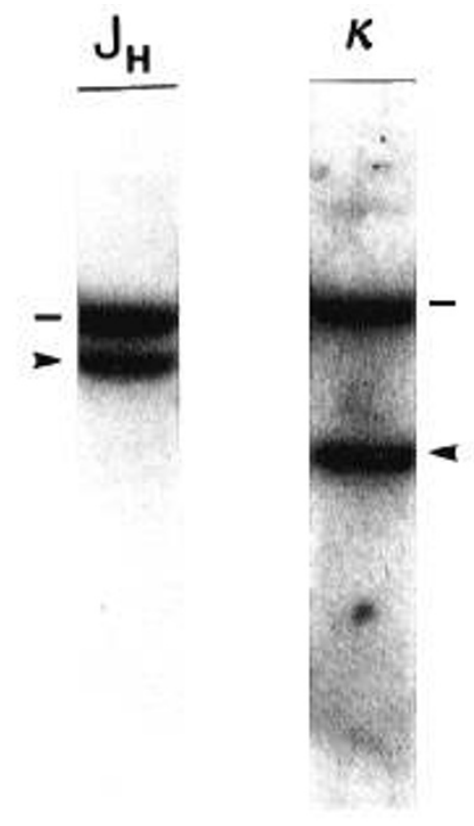

Fig. 4. Autoradiograms of immunoglobulin gene rearrangement analyses. On the left is shown the analysis of immunoglobulin heavy chain DNA using the $\mathrm{J}_{\mathrm{H}}$ hybridization probe; on the right is the analysis using the $\kappa$ light chain probe. Dashes indicate germline bands and arrowheads indicate clonally rearranged bands. Both analyses were performed after digestion of DV-1 DNA with Bam HI-restriction enzyme.

dilution. By contrast both DV-1 and LA-350 showed a substantial dose dependent inhibition of $\left[{ }^{3} \mathrm{H}\right] \mathrm{dTh}$ uptake in response to incubation with SAC. Maximal inhibition occured at a 1:50 dilution of SAC with 75 and $73 \%$ inhibition for DV-1 and LA350 , respectively. It should be noted that baseline $\left[{ }^{3} \mathrm{H}\right] \mathrm{dTh}$ incorporation for unstimulated LA-350 under these culture conditions is 200-fold greater and for DV-1 10-fold greater than baseline for unstimulated PBL.

Other studies. Immunoglobulin secretion of DV-1 and LA350 was determined by quantitation of supernatants from cultures intially seeded at a cell density of $5 \times 10^{4}$ cells $/ \mathrm{ml}$ in Costar $25-\mathrm{mm}$ flasks. Samples were harvested by centrifugation at 1000 $\times \mathrm{g}$ for $10 \mathrm{~min}$ at varying incubation times and supernatants were stored at $-20^{\circ} \mathrm{C}$ until assayed. Using the ELISA methods described above no $\operatorname{IgG}$ was detected and the $\operatorname{IgM}$ content of DV-1 and LA-350 supernatants ranged from 900 to $1200 \mathrm{ng} / \mathrm{ml}$ and 200 to $400 \mathrm{ng} / \mathrm{ml}$, respectively, depending on the culture conditions. No specific binding activity for either EBV antigens by indirect immunofluorescence (Dr. Ciro Sumaya, San Anton nio, TX) or for neuroblastoma surface antigens by radioimmunoassay (16) was noted in respective supernatants.

\section{DISCUSSION}

The clinical data on the patient from whom this cell line was produced have been reported recently $(5,14)$. To summarize his immunological status, he had always shown absolute lymphopenia generally with absolute counts of approximately 400 cells/ $\mathrm{mm}^{3}$. Total $\mathrm{T}$-cells by $\mathrm{E}$ rosettes usually ranged from $5-15 \%$ (normal 43-81\%) and slg+ lymphocytes were usually elevated, ranging from $15-49 \%$ (normal $6-18 \%$ ). Most of the B-cells stained for $\operatorname{IgM}$ and $\operatorname{IgD}$ but lacked $\operatorname{IgG}$ and $\operatorname{IgA}$. Monoclonal antibody staining of surface markers showed T3, T4, T8, and T11 consistently below $25,14,10$, and $23 \%$, respectively, for at least 2 yr prior to transplantation. The B-cell markers la 1 and B1 were usually elevated at 68 and $45 \%$, respectively. Functionally, serum immunoglobulin levels for $\operatorname{IgG}, \operatorname{IgA}$, and $\operatorname{IgM}$ were consistently $<10,20$, and $50 \mathrm{mg} / \mathrm{dl}$, respectively, with no evidence for specific antibody production to diphtheria, tetanus, or blood group antigens. In vitro proliferation studies to PWM, PHA, Con-A, and several bacterial and fungal antigens was consistently depressed, but MLC reactivity was present.

DV-1 shows many of the characteristics that have been attributed to EBV-derived LBLs. This line arose spontaneously with a relatively short delay period (only $2-3 \mathrm{wk}$ ) and cell growth was dependent on the presence of a "feeder" layer for 60-90 days. Subsequently the line grew independently in suspension demonstrating the typical pattern of growth and "classic" lymphoblastoid morphology. The cells were pleomorphic in culture and had a baseline $\left[{ }^{3} \mathrm{H}\right] \mathrm{d}$ Thd incorporation $60-100$ times that of normal unstimulated PBL. The presence of predominantly $\operatorname{IgM}_{*}$ with some expression of IgD by these cells and the absence of chromosomal abnormalities distinguish them from most Burkitt's lymphoma lines and other clonally transformed non-Hodgkin's lymphoma cell lines. The B-cell origin of these cells is suggested by the presence of membrane bound $\operatorname{IgM}$ and $\operatorname{IgD}, \mathrm{Dr}$, $\mathrm{B} 4, \mathrm{~B} 7, \mathrm{~B} 1$, and 37.1 surface markers and the absence of the common T-cell markers T3, T4, T8, and T11. The cells were not responsive to stimulation with either PHA or the T-celldependent PWM, whereas B-cell activators SAC and antiserum to $\mu$-heavy chains showed significant inhibitory and stimulatory effects, respectively. Both LA-350 and DV-1 cells differed from PBL in their lack of enhancement of anti- $\mu$-induced proliferation by the BCFG-containing supernatant. Although there appeared to be some reversal of the anti- $\mu$-stimulated proliferation of LA 350 by BCGF, the DV-1 cells showed no such reversal in the presence of $\mathrm{BCGF}$.

The host derivation of DV-1 was confirmed by the $46 \mathrm{XY}$ karyotype and the HLA phenotype. Virtually $100 \%$ of these cells were positive for EBNA on fluorescence and the presence of 
Table 2. Spontaneous and induced proliferation of PBL and LBLS

\begin{tabular}{|c|c|c|c|c|c|c|c|c|}
\hline \multirow{3}{*}{$\begin{array}{c}\text { Cell type } \\
\text { Mitogen: } \\
\text { Concentration: }\end{array}$} & \multicolumn{8}{|c|}{ CPM $\left[{ }^{3} \mathrm{H}\right] \mathrm{dThd}$ incorporated } \\
\hline & \multirow[b]{2}{*}{ None } & \multicolumn{3}{|c|}{ PHA } & \multirow[b]{2}{*}{ None } & \multicolumn{3}{|c|}{ PWM } \\
\hline & & $0.1 \mu \mathrm{g} / \mathrm{ml}$ & $1 \mu \mathrm{g} / \mathrm{ml}$ & $10 \mu \mathrm{g} / \mathrm{ml}$ & & $1: 5120$ & $1: 2560$ & $1: 640$ \\
\hline PBL & $\begin{array}{r}1558 \\
\pm 88\end{array}$ & $\begin{aligned} & 5442 \uparrow \\
\pm & 1340\end{aligned}$ & $\begin{array}{c}216501 \dagger \\
\pm 8641\end{array}$ & $\begin{array}{l}267022 \uparrow \\
\pm 10757\end{array}$ & $\begin{array}{r}2135 \\
\pm 218\end{array}$ & $\begin{array}{l}30122 \dagger \\
\pm 2143\end{array}$ & $\begin{array}{l}37271 \dagger \\
\pm 1655\end{array}$ & $\begin{array}{l}42389 \dagger \\
\pm 2014\end{array}$ \\
\hline DV-1 & $\begin{array}{l}40217 \\
\pm 1321\end{array}$ & $\begin{array}{c}38568 \\
\pm 3442\end{array}$ & $\begin{array}{c}35450+ \\
\pm 1437\end{array}$ & $\begin{array}{l}24866 \dagger \\
\pm 1190\end{array}$ & $\begin{array}{r}41244 \\
\pm 1293\end{array}$ & $\begin{array}{r}40445 \\
\pm 2459\end{array}$ & $\begin{array}{r}42148 \\
\pm 1562\end{array}$ & $\begin{array}{r}42531 \\
\pm 872\end{array}$ \\
\hline LA- -350 & $\begin{array}{r}310825 \\
\pm 5476\end{array}$ & $\begin{array}{r}264911 \\
\pm 48934\end{array}$ & $\begin{array}{l}275976 \neq \\
\pm 16747\end{array}$ & $\begin{array}{c}256333 \dagger \\
\pm 6733\end{array}$ & $\begin{array}{r}289736 \\
\pm 12941 \\
\end{array}$ & $\begin{array}{r}288763 \\
\pm 8441 \\
\end{array}$ & $\begin{array}{r}293698 \\
\pm 13893 \\
\end{array}$ & $\begin{array}{r}311567 \\
\pm 7820 \\
\end{array}$ \\
\hline
\end{tabular}

* Incorporation of $\left[{ }^{3} \mathrm{H}\right] \mathrm{d}$ Thd after a 72 -h incubation of each cell type with the specified concentrations of mitogen. Initial cell numbers were: PBL $-1 \times 10^{5}, \mathrm{DV}-1$ and LA-350-1 $1 \times 10^{4}$ cells/culture. Data are from a representative experiment performed in quadruplicate.

$\dagger p \leq 0.001$.

$\ddagger p \leq 0.01$.

Table 3. Effect of anti- $\mu$ on proliferation*

\begin{tabular}{|c|c|c|c|c|c|c|c|}
\hline \multirow[b]{2}{*}{ Ccll type } & \multirow[b]{2}{*}{ BCGF } & \multicolumn{6}{|c|}{ Anti $-\mu$ concentration $(\mu \mathrm{g} / \mathrm{ml})$} \\
\hline & & 0 & 5 & 11 & 22 & 44 & 175 \\
\hline \multirow[t]{2}{*}{ LA350 } & & 140,800 & 149,106 & $155,173 \dagger$ & $151,694 \ddagger$ & 135,797 & $119,238 \ddagger$ \\
\hline & & $\pm 1,092$ & $\pm 7,187$ & $\pm 7,762$ & $\pm 2,885$ & $\pm 8,490$ & $\pm 5,774$ \\
\hline \multirow[t]{2}{*}{ DV -1} & & 19,523 & $30,940 \ddagger$ & $30,647 \ddagger$ & $29,037 \dagger$ & $27,321 \dagger$ & $24,709+$ \\
\hline & & \pm 536 & $\pm 1,192$ & $\pm 1,826$ & $\pm 4,122$ & $\pm 2,993$ & $\pm 2,856$ \\
\hline \multirow[t]{2}{*}{ PBL } & & 1,209 & $3,949 \ddagger$ & $2,522 \dagger$ & $1,935 \ddagger$ & 1,511 & 882 \\
\hline & & \pm 156 & \pm 503 & \pm 437 & \pm 126 & \pm 525 & \pm 102 \\
\hline \multirow[t]{2}{*}{ LA350 } & $20 \%$ & 141,134 & 142,807 & 141,548 & 137,346 & 138,905 & 133,936 \\
\hline & & \pm 818 & $\pm 6,484$ & $\pm 3,754$ & $\pm 4,328$ & $\pm 2,463$ & $\pm 4,599$ \\
\hline \multirow[t]{2}{*}{ DV-1 } & $20 \%$ & 19,368 & $30,909 \ddagger$ & $28,475 \ddagger$ & $27,918 \dagger$ & $27,523 \dagger$ & $26,281+$ \\
\hline & & \pm 857 & $\pm 1,789$ & $\pm 2,024$ & $\pm 3,050$ & $\pm 2,962$ & $\pm 1,619$ \\
\hline \multirow[t]{2}{*}{ PBL } & $20 \%$ & 1,970 & $6,179 \ddagger$ & 3,691‡ & $3,606 \ddagger$ & 4,448 & $2,994 \dagger$ \\
\hline & & \pm 254 & \pm 670 & \pm 601 & \pm 194 & $\pm 1,954$ & \pm 478 \\
\hline
\end{tabular}

* Values represent mean cpm \pm SD. $\left[{ }^{3} \mathrm{H}\right] \mathrm{dThd}$ incorporated by $1 \times 10^{5} \mathrm{PBL}$ or $1 \times 10^{4} \mathrm{LBL}$ from $24-48 \mathrm{~h}$ with varying concentrations of rabbit $\mathrm{F}\left(\mathrm{ab}^{\prime}\right)_{2}$ anti-lgM ( $\mu$-specific) in the presence or absence of BCGF. Values represent normalized data from two experiments with overlapping concentration ranges run in quadruplicate.

$\dagger p \leq 0.01$.

$\forall p \leq 0.001$.

Table 4. Effect of SAC on proliferation*

\begin{tabular}{lccr}
\hline $\begin{array}{c}\text { SAC final } \\
\text { dilution }\end{array}$ & LA-350 & DV-1 & \multicolumn{1}{c}{ PBL } \\
\hline (Media only) & $310,882 \pm 6,663$ & $24,780 \pm 602$ & $1,647 \pm 222$ \\
$1: 50$ & $86,126 \pm 3,414$ & $6,677 \pm 698$ & $5,084 \pm 158$ \\
$1: 100$ & $147,501 \pm 5,117$ & $11,812 \pm 1,232$ & $9,835 \pm 548$ \\
$1: 500$ & $278,854 \pm 8,436$ & $19,255 \pm 2,048$ & $15,204 \pm 427$ \\
$1: 1000$ & $264,721 \pm 13,605$ & $20,256 \pm 937$ & $14,877 \pm 549$ \\
$1: 5000$ & $255,374 \pm 12,329$ & $19,166 \pm 480$ & $15,335 \pm 811$ \\
\hline
\end{tabular}

* Values represent mean $\mathrm{cpm} \pm \mathrm{SD}$ and normalized to the mean of values for overlapping dilutions of SAC for two experiments run in quadruplicate. $p \leq 0.001$ for all values compared to unstimulated control $\mathrm{cpm}$.

EBV DNA was confirmed by hybridization studies. The finding of 5-10 EBV genome equivalients per cell and the spontaneous in vitro production of $900-1200 \mathrm{ng} / \mathrm{ml}$ of IgM are comparable with other EBV transformed LBLs which have been studied (2).

Two features distinguish DV-1 from most other LBL. Outgrowth of DV-1 showed a 2- to 3-wk "lag" period. Although somewhat subjective this is clearly different from the $30-100$ days reported for most $\mathrm{LBL}$ from infectious mononucleosis patients and more closely resembles outgrowth of Burkitt's lymphoma lines (15). Abnormal T-cell restraint of rapid proliferation of nonpermissively EBV-infected B-cells may have encouraged the early outgrowth of DV-1 $(17,18)$.

The typical polyclonal LBLs arising from B-cells infected with $\mathrm{EBV}$ naturally or in vitro may become monoclonal after periods of $1 \mathrm{yr}$ or longer $(2,19)$. The monoclonality of DV-1 suggested by the virtual absence of $\lambda$ light chain and confirmed by Ig gene rearrangement (Fig. 4) was detected in the 2 nd month of culture. Early monoclonal restriction might be explained by the preexistent B-cell defect demonstrated in 1979 prior to EBV exposure (14), the lack of normal T-cell control of isotype diversity, or the selective in vitro outgrowth of B-cells present in the marrow which were already monoclonally transformed but not detectable grossly or microscopically.

The stage of maturation of DV-1 may be analyzed by the expression of various surface differentiation antigens. The typical B-cell differentiation antigens B1, B4, and B7 as well as coexpression of $\operatorname{IgM}$ and $\operatorname{IgD}$ imply differentiation to a mature but "naive" B-cell. Moreover, the B2 marker, associated with the EBV receptor and demonstrated to show activation and cell cycle-dependent expression (20), was demonstrated on roughly $30 \%$ of unsynchronized cells.

The correlation between EBV immortalization and immunoglobulin secretion has been demonstrated in two recent reports $(21,22)$. While it is clear that only about $50 \%$ of normal B-cells capable of stimulated immunoglobulin secretion are immortalized by EBV (21), it is not clear what relationship the pattern of antigenic expression on DV-1 has with respect to its functional properties of spontaneous IgM secretion or the specific, although modest, modulation of proliferative activity of LA-350 and DV1 by SAC and anti- $\mu$. These findings are compatible with functional studies on malignant B- and T-cells reported by other authors $(23,24)$. Such modest effects on DNA synthesis and cell proliferation triggered by activation events at the cell membrane have been associated with dramatic effects on cellular metabo- 
lism and constitutive synthesis of a number of glycoprotein receptors and phospholipid turnover (25-28).

It would appear from our preliminary observations that these LBLs may be subject to some of the same regulatory mechanisms as normal B-cells, and further study of this LBL model system holds significant potential for the effective production of human monoclonal antibodies by LBL, the elucidation of some mechanisms involved in viral B-cell activation, and the clarification of some intrinsic B-cell defects present in patients with humoral immunodeficiencies.

Acknowledgments. The authors thank Dr. D. Ledbetter for performing cytogenetic analysis; Dr. C. V. Sumaya for performing EBV serological testing and immunofluorescence; Dr. R. D. Feigin for manuscript review; and Ms. T. McCumber for manuscript preparation.

\section{REFERENCES}

1. Epstein MA, Achong BG (eds) 1979 The Epstein-Barr Virus. Springer-Verlag, New York

2. Nilsson K, Klein G 1982 Phenotypic and cytogenetic characteristics of human B-lymphoid cell lines and their relevance for the etiology of Burkitt's lymphoma. Advan Cancer Res 37:319-380

3. Rosenblatt HM, Shearer WT Immunodeficiency and cancer. In: Finegold M, Weinberg A (eds) Pediatric Ncoplasia in Childhood and Adolescence, Vol 18. WB Saunders, Philadelphia, pp 31-45

4. Boyum A 1968 Separation of leukocytes from blood and bone marrow. Scand J Clin Lab lnvest 21: (suppl 97):77-89

5. Shearer WT, Ritz J, Finegold MJ, Guerra IC, Rosenblatt HM, Lewis DE, Pollack MD, Taber LH, Sumaya CV, Grumet FC, Cleary ML, Warnke R, Sklar J 1985 Epstein-Barr virus-associated B-cell proliferations of diverse clonal origins after bone marrow transplantation in a 12-year old patient with severe combined immunodeficiency. N Engl J Med 312:1151-1159

6. Lewis DE, Cook RG, Rossen RD, Shearer WT 1985 Detection of a novel differentiation antigen on immunodeficient B cells. Fed Proc 44:976

7. Henle W, Henle GE, Horwitz CA 1974 Epstein-Barr virus specific diagnostic tests in infectious mononucleosis. Hum Pathol 5:551-565

8. Sumaya CV, Ench Y, Pope RM 1982 Improved test for IgM antibody to Epstein-Barr virus using an absorption step with Staphylococcus aureus. J Infect Dis 146:518-523

9. Grogan E, Miller G, Henle W, Ralson M, Shedd D, Niederman JC 1981 Expression of Epstein-Barr viral early antigens in monolayer tissue cultures after transfection with viral DNA and DNA fragments. J Virol 40:861-869

10. Cleary ML, Chao J, Warnke R, Sklar J 1984 Immunoglobulin gene rearrangement as a diagnostic criteria of B cell lymphoma. Proc Natl Acad Sci USA 811:593-597

11. Engvall E, Perlmann P 1972 Enzyme linked immunosorbent assay, ELISA III. Quantitation of specific antibodies by enzymed-labeled anti-immunoglobu- lin in antigen-coated tubes. J Immunol 109:129-135

12. Lane HC, Volkman DJ, Whalen G, Fauci AS 1981 In vitro antigen-induced, antigen-specific antibody production in man; specific and polyclonal components, kinetics, and cellular requirements. J Exp Med 154:1043-1057

13. Mulivor RA, Borcelli D, Harris H 1985 Quantitative analysis of alkaline phosphatases in serum and amniotic fluid: comparison of biochemical and immunologic assays. J Lab Clin Med 105:342-348

14. Paschall VL, Brown LA, Lawrence EC, Karol RA, Lotzova E, Brown BS, Shearer WT 1984 Immunoregulation in an isolated 12-year old boy with congenital severe combined immunodeficiency. Pediatrics 18:723-728

15. Sredni B, Sieckmann DG, Kumagai S, House S, Green I, Paul WE 1981 Longterm culture and cloning of nontransformed human B lymphocytes. J Exp Med 154:1500-1516

16. Zeltzer PM, Secger RC 1977 Radioiodinated protein A from Staphylococcus aureus microassay for antibodies bound to cell surface antigens of adherent tumor cells. J Immunol Methods 17:163-175

17. Purtilo D, Harada S, Bechtold T, Yetz J, Rogers G, Seshi B 1984 Immunoregulatory defects and Epstein-Barr virus-associated lymphoid disorders. In: Magrath IT, O'Connor AT, Ramot B (eds) Pathogenesis of Leukemias and Lymphomas: Environmental Influences. Raven Press, New York, pp 235257

18. Tosato G, Magrath IT, Blacsc RM $1982 \mathrm{~T}$-cell mediated immunoregulation of Epstein-Barr virus (EBV) induced B-cell activation in EBV seropositive and EBV-seronegative individuals. J Immunol 128:575-579

19. Brown NA, Miller G 1982 Immunoglobulin expression by human B lymphocytes clonally transformed by Epstein-Barr virus. J Immunol 128:24-29

20. Anderson KC, Boyd AW, Fisher DC, Slaughenhaupt B, Groopman JE, O'Hara CJ, Dalcy JF, Schlossman SF, Nadler LM 1985 Isolation and functional analysis of human $\mathrm{B}$ cell populations $\mathrm{I}$. Characterization of the $\mathrm{BI}^{+} \mathrm{B2}^{+}$, and $\mathrm{B} 1^{+} \mathrm{B}^{-}$subsets. J Immunol 134:820-827

21. Tosatao G, Blaese RM, Yarchoan R 1985 Relationship between immunoglobulin production and immortalization by Epstein-Barr virus. J Immunol 135:959-964

22. Bird G, Britton S, Ernberg I, Nilsson K 1981 Characteristics of Epstcin-Barr virus activation of human B lymphocytes. J Exp Med 154:832-839

23. Mayer L, Posnett DN, Kunkel HG 1985 Human malignant T cells capable of inducing an immunoglobulin class switch. J Exp Med 161:134-144

24. Smith JL, Gorden J 1980 Immunoglobulin synthesis by ncoplastic cells: models of a clonal transition from $\operatorname{lgM}$ to $\lg$ A synthesis. J Clin Pathol 33:539-554

25. Cambier JC, Monroc JG $1984 \mathrm{~B}$ cell activation vs. differentiation signaling of $B$ cell membrane depolarization, increased $I-A$ expression, $G_{0}$ to $G_{1}$ transition, and thymidine uptake by anti-IgM and anti-IgD antibodies. J Immunol 133:576-581

26. Hamano T, Asofsky R 1983 Functional studies on B-cell hybridomas with Bcell surface antigens I. Effects of anti-immunoglobulin antibodics on proliferation and differentiation. J Immunol 130:2027-2032

27. Muraguchi A, Butler JL, Kehrl JH, Fauci AS 1983 Differential sensitivity of human B-cell subsets to activation signals delivered by anti- $\mu$ antibody and proliferative signals delivered by a monoclonal B-cell growth factor. J Exp Med 157:530-546

28. Shearer WT, Moore EG, Ulrich RG, Green CG, McClure JE 1984 Antibody to immunoselected L-cell antigens mimics stimulatory activity of antibody to whole L-cells. Cell Immunol 86:230-241 